\title{
Labor market segmentation and gender inequality in Cameroon
}

\author{
Ningaye Paul", Talla Fokam Dieu Ne Dort \\ Faculty of Economics and Management, University of Dschang, Cameroon \\ Email address: \\ paningaye@yahoo.fr (N. Paul), dtallafokam@yahoo.fr (T. F. D. N. Dort)
}

To cite this article:

Ningaye Paul, Talla Fokam Dieu Ne Dort. Labor Market Segmentation and Gender Inequality in Cameroon. International Journal of Business and Economics Research. Vol. 3, No. 2, 2014, pp. 89-98. doi: 10.11648/j.ijber.20140302.16

\begin{abstract}
This research seeks to propose ways to reduce gender inequality in the labor market in Cameroon. It uses the dynamic cloud classification to identify different segments of the labor market, the decomposition method of Oaxaca and Blinder to quantify the gender discrimination and to highlight the factors which provoke such discrimination. The results show that the Cameroonian labor market has three segments. The segment with the highest gender inequality is the informal agricultural sector, followed by the non-agricultural informal sector, and finally the formal sector. Our results also show that if we want a greater reduction of gender inequality, we must encourage women's access to secondary and higher education, encourage women's access to vocational training, and increase their number of years of professional experience.
\end{abstract}

Keywords: Segmentation, Labor Market, Gender Inequality

\section{Introduction}

According to the National Institute of Statistics [1, 2], Cameroon has strong gender disparities at various levels. At the level of education, the girl/boy ratio in primary education is estimated at 0.89 in 2007 against 0.83 in 2001: a slight improvement of 6 points. This report shows a decline of 7 points in secondary education where it dropped from 0.93 to 0.86 . At the economic level, the participation rate of women in the agricultural sector is estimated at $21.4 \%$ in 2007 , while that of men is $47.4 \%$. This gap is likely due to the difficulties faced by women (as compared to men) in terms of access to loans, to land, and to means of production. As to health, the third demographic and health survey carried out in 2004 shows that the prevalence of HIV/AIDS on that date was $5.5 \%$ for women and $4.1 \%$ for men aged between 15 and 49. Using a synthetic approach, the Global Report on Human Development submitted by the United Nations Program for Development [3] shows that the Human Development Index Gender is estimated at 0.515 for Cameroon in 2007; which ranks it number 129 out of 155 countries. It is worth noting that the Gender-Index is the Human Development Index adjusted to gender inequality. It confirms the reality of gender inequality within the country.

In addition, Cameroon has set a number of objectives related to human development in the context of the emergence in 2035 . For example, the poverty rate estimated at $39.9 \%$ in 2007 should be reduced to $10 \%$, by the emergence period. However, gender inequalities are incompatible with such prospects for human development, because of their economic and social consequences. At the economic level, several studies show that gender inequalities in getting access to education and employment have a negative impact on economic growth [4, 5]. Klasen [6] finds that Cameroon loses about $0.5 \%$ economic growth per capita and per year, as a result of gender inequalities. At the social level, the position occupied by a woman in the household or society has repercussions on both her family (control of her fertility level, children's education and health) and on society as a whole. Costa and Silva [7] reported that the reduction of gender inequality do not only benefit women but also men, children and the elderly, the poor as well as the rich. The reason is that women's incomes are much more oriented towards the supplying for the basic needs of the household, and thereby contributes to the reduction of poverty $[8,9]$. Therefore, the benefit obtained from the reduction of gender disparities is not only macroeconomic: the social role of women testifies to this fact. It is probably for these reasons that the fight against gender inequality is among the eight Millennium Development Goals. But the main concern is how to 
achieve this goal. This research seeks to address that issue.

Given that it is from the labor market that individuals derive most incomes needed to improve their living conditions, several authors propound that the eradication of inequalities between men and women in the labor market is the primary means of fighting against gender discrimination. The elimination of inequalities, in turn, has an impact on the economic growth and on the improvement of development indicators. For example, well-paid jobs for women appear to be necessary to enforcing the rights of women, and to achieving greater development goals; such as economic growth, poverty reduction, health, education and the control of the fertility level.

The main objective of this research is to propose ways and means for reducing gender inequalities in the labor market in Cameroon. Most specifically, it is to: (1) segment the Cameroonian labor market, (2) quantify gender inequality in each segment and determine the factors of discrimination, and (3) propose ways of reducing gender inequality, on the basis of discriminatory factors identified in (2).

On the methodological level, the segmentation of the labor market is obtained by the method of classification by dynamic cloud. Oaxaca's method [10] and Blinder's method [11], applied to the wage equations, is used to quantify gender inequality in the various market segments.

This work presents a two-fold contribution: first, some previous studies have proceeded by a segmentation of the labor market a priori [12, 13]. This method allows the researcher to define a number of segments and to test the discrimination between them. Even so, it involves the arbitrary construction of segments. Other works Leduc and Geneva [14] have used hierarchical clustering to segment the labor market. This method involves the construction of a dendrogram whose branches constitute the different segments of the labor market. However, the main limitation of this method is related to the difficulties of interpreting the results when dealing with a larger sample (virtually greater than 100). To overcome these limitations, we have used the classification by dynamic cloud. The latter goes through successive iterations, and at equilibrium, it affects individuals in homogeneous classes. It is the analysis of these classes which assesses market segments. Second, it enables the researcher to do a two-fold assessment of gender inequality in the segments of the labor market: the difference between men and women in the participation at the labor market, then the wage gap between the two groups of people. This contribution thus permits to study explicitly the factors that guide individuals in different market segments, as well as the extent and causes of wage discrimination in these segments.

The remainder of this paper is organized as follows: Section 2 is devoted to the review of literature. Section 3 analyses gender discrimination in the labor market in Cameroon. Section 4 discusses the methodology. Section 5 presents the results and discussions. Section 6 is a conclusion with emphasis on recommendations of economic policies.

\section{Review of Literature}

Gender inequality is the discrimination between men and women, with regard to access to important economic and social goods. In the framework of the labor market, this inequality manifests itself either in terms of difference in the participation, between men and women, in the labor market or in certain market segments, or by a significant gap in the wages, between men and women who have similar professional skills (academic qualifications, for example) for a particular service. Two economic theories explain the roots and causes of gender inequality in the labor market: the neoclassical theory of the labor market; which focuses on individual choices, and the theory of feminist economists; which focuses on social norms and constraints of structural order.

\subsection{The Neoclassical Approach to Gender in the Labor Market}

Based on preference scales, this approach is ranked among the first works on gender and labor market. These scales, which are on the basis of the differentiated effects in the labor market, are such that workers maximize their usefulness while companies maximize their profit. This approach is based on three series of works.

The first series shows that women are generally more vulnerable at the educational level, and that the differentiated labor market effects are due to the differentiated investment of human resources according to gender $[15,16]$. Thus, the low level of women's education reflects their commitment to domestic work, on the one hand, and their low participation in the labor market, on the other. In addition, when entering the labor market, their choice is usually oriented towards activities consistent with their domestic work. This is how women are, for the majority of them, represented in areas of low wage jobs, and are characterized by job instability.

As a matter of fact, an empirical study by the International Labor Organization [17] reveals that women account for about $60 \%$ of the world population and $40.4 \%$ of the workforce. In addition, the low proportion of women in the labor market is not evenly distributed; especially when one considers the occupational groups of the various market sectors. Thus $46.3 \%$ of employed women work in the service sector, $35.4 \%$ in agriculture, and only $18.3 \%$ in the industry sector (against $26.6 \%$ of men).

This "illustration" points not only to the choices made by women and their position in the labor market, but also to the concept of segmentation of the labor market. The segmentation of the labor market is based on the principle that the labor market is divided into several segments. Some segments generate incomes and thereby provide stability and security to professional careers, while others generate low wages and thus cause employment instability and financial insecurity.

The second series, called "monopoly power" suggests that gender inequalities in the labor market reflect a 
tendency to discrimination by individual employers [18, 19]. This tendency is noticeable namely, in certain reluctance from the part of employers when it comes to hiring women or in the exclusion of women from a number of jobs supposedly reserved for men. The authors cited above have provided some explanations to the disadvantaged position of women in the labor market. They support the idea that women are physically weaker and more absorbed by domestic concerns, and therefore cannot be as effective in their work as men. This justifies the wage and employment gaps between men and women in the labor market.

The third series focuses on statistical discrimination. It shows that under the basis of imperfect information available to them, employers use group characteristics (such as the group averages in academic qualifications) to formulate judgments about the ability of all members of this group to individual work. Thus, two individuals of different sexes may be treated differently even though they were identical in all other respects [20].

In sum, the neoclassical approach to gender in the labor market has a significant advantage in the sense that it permits to identify and measure gender discrimination. Its main shortcoming is that it does not permit the reader to understand the processes that generate this discrimination. Such a shortcoming is addressed by the feminist economists approach.

\subsection{Feminist Economists Approach to the Labor Market}

This approach suggests that inequality between men and women in the labor market cannot be explained only by individual choices $[21,22,23]$. The authors who propound this theory show that the disadvantages of women are imposed by the structural distribution of rules, standards and assets, and by the different identities of their society. One of the simplest reasons is that women are not subject to the same conditions of life and work in different regions of the world; and even in different countries. But in general, they occupy a position of "dominated" people. For instance, Bergman [24] showed that women today are comparable to Blacks at the time of colonization. In addition, Phillips and Taylor [25] suggested that women's work was considered "lower", not because their work was inferior, but because they were considered "carriers of inferiority".

Therefore, the approach of gender inequalities defended by feminist economists is closer to the concept of inequality of opportunities developed by Arneson [26] and Roemer [27]. According to these two authors, opportunities are factors that are imposed on individuals, and they are not dependent on people's will or choice. There is inequality of opportunities when the distribution of indicators of well-being (income, education, employment, health) depends on the circumstances of individuals. Consequently, they consider gender, parental status, ethnicity and place of birth as circumstances. Thus, it seems obvious that the preferences of individuals in the labor market may be influenced by gender.

\section{Gender Discrimination in the Labor Market in Cameroon}

In this section, we present the level of participation in the labor market, the state of jobs in Cameroon, and the structure of employment in Cameroon for people of working age (over 10 years). This section is inspired by the main report submitted by the National Institute of Statistics of Cameroon [28] on the second Survey of Employment and Informal Sector in Cameroon (SEIS2).

\subsection{Activity Rate, Employment Rate and Gender Discrimination}

The ratio of activity according to the International Labor Office (ILO) is estimated at $69 \%$ in Cameroon in 2010. Rural areas recorded a higher contribution compared to urban areas $(75.7 \%$ in rural areas against $59.5 \%$ in urban areas). In the classification by sex, the rate is $74.1 \%$ for men against $64.2 \%$ for women. In rural areas, $67.2 \%$ of men are active against $52.2 \%$ women: a difference of 15 points. This gap is smaller in urban areas and is about 6.4 points; with nearly eight out of ten active men, against seven out of ten women.

The employment rate dropped slightly by 1.9 points, between 2005 and 2010, and reached $66.4 \%$ in 2010. Rural areas recorded the highest employment rate $(74.6 \%$ in 2010) against $54.7 \%$ for urban areas. In the classification by sex, the gap between the employment rates of men and women is estimated at around 19 points in favor of men.

Overall, there was a decline in unemployment from $7.5 \%$ in 2005 to $5.4 \%$ in 2010 . Women and urban areas recorded the highest unemployment rate $(6.7 \%$ and $7.6 \%)$ against $4.1 \%$ and $2.5 \%$ for men and rural areas.

\subsection{Academic Qualifications, Employment and Gender Discrimination}

More than half of the employed populations have a level of education equal to or lower than primary education (52.6\%), 39.3\% have been to secondary school, and 8.2\% have gone through higher education. This concentration of workforce of low level of education thus appears as an obstacle to obtaining decent jobs. The level of education also remains very low among women. In fact, over $60 \%$ of women have the primary education: this explains their predominance in the informal sector.

\subsection{Structure of Employment in Cameroon and Gender Discrimination}

The structure of the labor market in Cameroon is dominated by the informal sector $(90.5 \%$ of assets which occupied $37.5 \%$ in the non-agricultural sector and $53 \%$ in the agricultural sector). The formal private sector employs $3.7 \%$ of the workers and the public sector $5.8 \%$. According to sex, men are more employed in the labor market than women $(52.2 \%$ men against $47.8 \%$ of women). In addition, $7.2 \%$ and $5.2 \%$ of men have their jobs in the public and formal private sectors, 
respectively; against $4.3 \%$ and $1.9 \%$ for women.

Depending on the nature of production activities, more than half of workers (53.3\% of employed persons) are engaged in the primary sector, $12.6 \%$ work in industry, and $34.1 \%$ in the tertiary sector (commerce and services). According to sex, women outnumber men in the primary sector $(58.1 \%$ against $48.9 \%)$.

Depending on employment status, more than $50 \%$ of women work on their own account and $37.2 \%$ of women are caregivers or apprentices. These proportions are between $44.3 \%$ and $22.3 \%$, respectively, for men.

Depending on the socio-economic groups, men are more likely to occupy positions of executive or boss, compared to women. In fact, $6 \%, 2.3 \%$, and $3.6 \%$ of men occupy the positions of staff in the public sector, staff or executive in the formal private sector, and boss in the informal (non-agricultural) sector, respectively; against $3.3 \%, 0.9 \%$, and $1.5 \%$ for women.

\subsection{Wages and Gender Discrimination}

The average hourly earnings of workers in 2010 are estimated two times higher for men than for women; especially for those aged more than 10. NIS statistics show that this remuneration is $359.5 \mathrm{CFA} F$ for males against 180.5 for women [29]. As to the monthly average salary (or income), it is estimated at 59,681 for men, against 28,270 CFAF for women: thus a male / female ratio of 2.11 .

\section{Methodology}

\subsection{Labor Market Segmentation by Dynamic Cloud Classification}

According to the work by Brilleau, Coulibaly, Gubert, Koriko, Kuepie and Ouedraogo [30], it appears that African labor markets are compartmentalized into segments in which the structures and mechanisms for salary, career prospects, and job security are different. Therefore, a comprehensive study in the labor market requires an exploration into the different market segments. We shall thus proceed to the segmentation of the labor market in Cameroon.

In the economic literature, two methods are used to examine the segmentation of the labor market. The first defines the segments a priori and the second defines the segments a posteriori. The first method is therefore based on the arbitrary, as it first identifies the segments. The second method on the contrast, involves techniques of automatic classification of groups. These techniques include segments of individuals characterized by high internal homogeneity and high external heterogeneity on the basis of indicators [14]. The indicators used for this segmentation are: gender, level of education, place of residence, type of employment, income from main activity (in quintiles), the socio-professional category, and marital status. Given the large size of the sample $(38,599$ individuals), and the fact that the hierarchical clustering method handles only small samples sizes, the classification technique used in this study is the classification by dynamic cloud. This classification works by successive iterations. Convergence is reached when, after several iterations, we obtain a stable solution. This is a situation where it is no longer possible to change the segment of an individual.

We have applied this technique on our data and have tried several classes. At the end, the smallest convergence has been obtained for two classes; and after only 12 iterations, as shown in the analysis report below.

Table 1. Classification of iterations in the labor market.

\begin{tabular}{ccc}
\hline Iteration & \multicolumn{2}{c}{ Changes in the centers classes } \\
& $\mathbf{1}$ & $\mathbf{2}$ \\
\hline 1 & 3.686 & 3.078 \\
2 & .357 & .222 \\
3 & .271 & .203 \\
4 & .181 & .157 \\
5 & .107 & .102 \\
6 & $6.204 \mathrm{E}-02$ & $6.108 \mathrm{E}-02$ \\
7 & $3.269 \mathrm{E}-02$ & $3.214 \mathrm{E}-02$ \\
8 & $1.908 \mathrm{E}-02$ & $1.881 \mathrm{E}-02$ \\
9 & $7.515 \mathrm{E}-03$ & $7.413 \mathrm{E}-03$ \\
10 & $1.251 \mathrm{E}-02$ & $1.246 \mathrm{E}-02$ \\
11 & $1.553 \mathrm{E}-03$ & $1.545 \mathrm{E}-03$ \\
12 & .000 & .000 \\
\hline
\end{tabular}

Convergence was reached - the distance is zero or very low. The maximum distance covered by a center is 000 . The current iteration is 12 . The minimum distance between initial centers is 9.747 .

Source: Authors' estimation with SPSS

At the end of the process, there are two classes in the Cameroonian labor market. Class 1 is made up of $51 \%$ of people, and class 2 is made up of $49 \%$.

\subsection{Gender Discrimination in the Labor Market Segments the Average Hourly Earnings of Workers}

To provide an empirical presentation of the situation of women in the various segments of the labor market in Cameroon, it is necessary to classify the segments according to their extent of wage discrimination; before determining the factors that lead to discrimination. Thus, we decompose each segment into two components. One of the components is explained from differences in individual characteristics. The other component is unexplained, and it results from the difference in the return of these characteristics [10, 11]. To materialize this wage gap in each segment, we use the wage equation developed by Mincer [31]. This equation consists of expressing the logarithm of wages of an individual as an equation of the characteristics of human capital, employment, and enterprise.

$$
W_{i s}=\beta_{S} X_{i s}+\varepsilon_{i s}
$$

$\mathrm{i}=1,2, \ldots$ represents individuals and we use $\mathrm{s}=m$ for males, and $f$ for women. $W_{i s}$ is the logarithm of earnings for men or for women; $\mathrm{X}$ is the set of explanatory variables that determine wages. These variables include the human capital 
characteristics (experience, education), the employment characteristics (socio-professional category, working conditions) and the characteristics of the company (size, sector of activity).

The wage gap between men and women in each segment is given by the equation:

$$
\bar{W}_{m}-\bar{W}_{f}=\beta_{m}\left(\bar{X}_{m}-\bar{X}_{f}\right)+\bar{X}_{f}\left(\beta_{m}-\beta_{f}\right)
$$

where $\bar{W}$ represents is the estimated average wages, the $\bar{X}$ represent the averages of the characteristics, and the $\beta$ are the yields of these characteristics; estimated in a wage equation. To highlight the decomposition of the wage gap, Oaxaca and Ransom [32] incorporate the $\beta_{n}$ standard in the gain function.

$$
\bar{W}_{m}-\bar{W}_{f}=\bar{X}_{m}\left(\hat{\beta}_{m}-\hat{\beta}_{n}\right)+\bar{X}_{f}\left(\hat{\beta}_{n}-\hat{\beta}_{f}\right)+\hat{\beta}_{n}\left(\bar{X}_{m}-\bar{X}_{f}\right)
$$

In this equation, $\bar{X}_{m}\left(\beta_{m}-\beta_{n}\right)$ is the male advantage (the surplus wages paid to men compared to normal), $\bar{X}_{f}\left(\beta_{n}-\beta_{f}\right)$ is the female disadvantage (the shortfall relative to normal), and $\beta_{n}\left(\bar{X}_{m}-\bar{X}_{f}\right)$ the wage gap due to a difference in characteristics between men and women.

Oaxaca and Ransom [32] suggest that researchers take as non-discriminatory standard, the results of the estimates of the wage equation for the entire population.

Since the incomes of individuals are potentially influenced by their non-random choice to belong to different segments of the labor market, Heckman [33] proposes a two-step method of adjusting individual choice. This method consists of estimating the probability of belonging to the group whose wages are observed, using a Probit model, calculating the inverse Mills ratio, and including it as an explanatory variable in the wage equation [34]. The variables of selection for participation in the labor market are: age, age squared, level of education, place of residence, number of young children (under 10 years), household size, and marital status.

\section{Data and Results}

\subsection{Data}

The data used in this study are from a secondary source and the first Survey of Employment and Informal Sector (SEIS1), carried out by the National Institute of Statistics of Cameroon (NIS) in 2005. SEIS1 contains 38,599 individuals, and it aims at analyzing in a general way, the labor market in Cameroon.

\subsection{Results and Discussions}

We shall present the results of the segmentation of the Cameroonian labor market, the estimates obtained from the wage equation in the different market segments, and an analysis of wage discrimination by gender in these segments, successively.

\subsubsection{Segmentation of the Cameroonian Labor Market}

The classification of individuals in the Cameroonian labor market has resulted into two employed classes. To switch the classification segmentation of the labor market, we decompose the two asset classes following the 6 main types of employment found in the Cameroonian labor market. The results are presented in Table 2.

Table 2. Breakdown of Classes by Types of Employment.

\begin{tabular}{lccc} 
& Class (dynamic clouds) & Total \\
& 1 & 2 & \\
\hline $\begin{array}{l}\text { Employee in the formal sector } \\
\text { Independent worker of the } \\
\text { formal sector }\end{array}$ & & $100.0 \%$ & $100.0 \%$ \\
$\begin{array}{l}\text { Independent worker of the } \\
\text { non-agricultural informal sector }\end{array}$ & $26.5 \%$ & $73.5 \%$ & $100.0 \%$ \\
$\begin{array}{l}\text { Independent worker of the } \\
\text { agricultural informal sector }\end{array}$ & $96.4 \%$ & $3.6 \%$ & $100.0 \%$ \\
$\begin{array}{l}\text { Employee of the } \\
\text { non-agricultural informal sector }\end{array}$ & $50.0 \%$ & $50.0 \%$ & $100.0 \%$ \\
$\begin{array}{l}\text { Employee of the agricultural } \\
\text { informal sector }\end{array}$ & $100.0 \%$ & & $100.0 \%$ \\
Total & $51.0 \%$ & $49.0 \%$ & $100.0 \%$ \\
\hline
\end{tabular}

Source: Authors' estimates

The observation of this decomposition reveals that all formal employees $(100 \%)$ are in Class 2 . This is the first segment we call Formal. $100 \%$ of employees of the agricultural informal sector and $96 \%$ of "self-employed" workers of the agricultural informal sector are in Class 1. They form the second segment we call agricultural informal sector. $73 \%$ of independent-non-agricultural-informal and 50 informal non-agricultural employees form a subclass of class 2. They are the third segment we call informal non-agricultural. These results are close to those obtained in previous studies with different methodologies. Thomas and Vallée [35] showed the existence of two segments of the labor market in Cameroon. These segments are the informal sector (unprotected); which has precarious working conditions, and the formal sector (protected); also called the "regulated sector". Njikam, Tchoffo and Mwaffo [12] divide the (independent unprotected and vulnerable) informal sector into three sectors, according to socio-professional categories.

From the results of this segmentation, it appears that the formal sector employs $21 \%$ of men against $8 \%$ of women. The latter are more represented in the informal agricultural sector (53.9\% of employed women against $46.1 \%$ of men). The non-agricultural informal sector has a non-discriminatory trend in terms of participation (Table 3).

Table 3. Characteristic of Segments According to Sex.

\begin{tabular}{llll}
\hline & Formal sector & $\begin{array}{l}\text { Non-agricultural } \\
\text { informal sector }\end{array}$ & $\begin{array}{l}\text { Agricultural } \\
\text { informal sector }\end{array}$ \\
\hline Male & $75,6 \%$ & $53,1 \%$ & $46,1 \%$ \\
Female & $24,4 \%$ & $46,9 \%$ & $53,9 \%$ \\
Total & $100 \%$ & $100 \%$ & $100 \%$ \\
\hline
\end{tabular}

Source: Authors' estimates, from SEIS1. 
Depending on the level of education, assets that have a high level of education are much more represented in the formal sector that offers good job security and payment. Accordingly, $72.5 \%$ of the employed in this sector have undergone higher education, $22.1 \%$ have a secondary education, $5.9 \%$ have a primary education, and $1.3 \%$ is unschooled. Moreover, the formal sector provides $47.2 \%$ of the salary of the fourth quintile (Table 4). On the other hand, the informal sector that provides undervalued compensation (abundance in the first and second quintile), has a strong representation of non-educated and active with primary education (Table 5).

Table 4. Characteristic of Segments According to Income Quintiles.

\begin{tabular}{lllll}
\hline Quintiles & $\begin{array}{l}\text { Formal } \\
\text { sector }\end{array}$ & $\begin{array}{l}\text { Non-agricultural } \\
\text { informal sector }\end{array}$ & $\begin{array}{l}\text { Agricultural } \\
\text { informal } \\
\text { sector }\end{array}$ & Total \\
\hline Q1 & $0,7 \%$ & $42,3 \%$ & $56,9 \%$ & $100 \%$ \\
Q2 & $1,7 \%$ & $52 \%$ & $46,2 \%$ & $100 \%$ \\
Q3 & $9,4 \%$ & $66,7 \%$ & $23,8 \%$ & $100 \%$ \\
Q4 & $47,2 \%$ & $43,5 \%$ & $9,3 \%$ & $100 \%$ \\
\hline
\end{tabular}

Source: Authors' estimates, from SEIS1

Table 5. Characteristics of Segments According to the Level of Education.

\begin{tabular}{lcccc}
\hline $\begin{array}{c}\text { Level of } \\
\text { Education }\end{array}$ & $\begin{array}{c}\text { Formal } \\
\text { sector }\end{array}$ & $\begin{array}{c}\text { Non-agricultural } \\
\text { informal sector }\end{array}$ & $\begin{array}{c}\text { Agricultural } \\
\text { informal } \\
\text { sector }\end{array}$ & Total \\
\hline $\begin{array}{l}\text { Unschooled } \\
\text { Primary }\end{array}$ & $1,3 \%$ & $44,3 \%$ & $54,4 \%$ & $100 \%$ \\
$\begin{array}{l}\text { Education } \\
\text { Secondary }\end{array}$ & $5,9 \%$ & $51,1 \%$ & $43,1 \%$ & $100 \%$ \\
$\begin{array}{l}\text { Education } \\
\text { Higher }\end{array}$ & $22,1 \%$ & $58 \%$ & $20 \%$ & $100 \%$ \\
Education & $72, \%$ & $24,5 \%$ & $2,6 \%$ & $100 \%$ \\
\hline
\end{tabular}

Source: Authors' estimates, from SEIS1

Other variables used in the segmentation played the role of complementary variables. These include the place of residence, socio-professional categories, and marital status.

Even so, they are important benefits for the informal sector: both in geographic terms (place of residence) and at the level of status within the service (socio-professional category). The statistics are grouped in tables 6 and 7.

Table 6. Characteristic of Segments According to the Place of Residence.

\begin{tabular}{lccc}
\hline & $\begin{array}{c}\text { Formal } \\
\text { Sector }\end{array}$ & $\begin{array}{c}\text { Non-agricultural } \\
\text { informal sector }\end{array}$ & $\begin{array}{c}\text { Agricultural } \\
\text { informal sector }\end{array}$ \\
\hline Rural & $24,2 \%$ & $32,2 \%$ & $81,3 \%$ \\
Urban & $75,8 \%$ & $67,8 \%$ & $18,7 \%$ \\
Total & $100 \%$ & $100 \%$ & $100 \%$ \\
\hline
\end{tabular}

Source: Authors' estimates, from SEIS1

Table 7. Characteristic of Segments According to Socio-professional Categories.

\begin{tabular}{lcccc}
\hline $\begin{array}{c}\text { Socio- } \\
\text { professional } \\
\text { Category }\end{array}$ & $\begin{array}{c}\text { Formal } \\
\text { Sector }\end{array}$ & $\begin{array}{c}\text { Non- } \\
\text { agricultural } \\
\text { informal sector }\end{array}$ & $\begin{array}{c}\text { Agricultural } \\
\text { informal } \\
\text { sector }\end{array}$ & Total \\
\hline $\begin{array}{l}\text { Staff } \\
\text { Employee }\end{array}$ & $48,5 \%$ & $8,4 \%$ & $0,1 \%$ & $100 \%$ \\
Own & $0,2 \%$ & $50 \%$ & $1,1 \%$ & $100 \%$ \\
$\begin{array}{l}\text { accounts } \\
\text { Laborer }\end{array}$ & $24,8 \%$ & $57,5 \%$ & $42,2 \%$ & $100 \%$ \\
$\begin{array}{l}\text { Apprentice, } \\
\text { family }\end{array}$ & $0,1 \%$ & $42,3 \%$ & $9,9 \%$ & $100 \%$ \\
assistance & & $57,6 \%$ & $100 \%$ \\
\hline
\end{tabular}

Source: Authors' estimates, from SEIS1

\subsubsection{Estimating Wage Equations and Pay Discrimination}

\subsubsection{Estimating Wage Equations}

Tables 8, 9 and 10 give us the results of the estimates of the wage equations in the different segments of the labor market. The wage equation allows the researcher to see the determinants of wages for each sex in each segment. From the preceding, we find the variables that discriminate men's wages compared to women's. Let us consider, for instance, the formal sector in Table 8. The modality "Secondary-Superior" is significant for women and not for men. We can then fill the wage gap by encouraging women's access to secondary and higher education. The same reasoning shows that the vocational training and the number of years of experience are the basic variables for reducing gender discrimination in the formal sector

Table 8. Estimates of the Wage Equation in the Non-Agricultural Sector.

\begin{tabular}{|c|c|c|c|c|c|c|}
\hline \multirow{2}{*}{ Variable } & \multicolumn{2}{|l|}{ Set } & \multicolumn{2}{|l|}{ Male } & \multicolumn{2}{|l|}{ Female } \\
\hline & Coef & P. value & Coef & P. value & Coef & P. value \\
\hline \multicolumn{7}{|c|}{ Level of Education (1) } \\
\hline Primary & 0,0489842 & 0,800 & $-0,0353316$ & 0,967 & 0,0390245 & 0,784 \\
\hline Secondary-higher & 0,3953027 & $0,048 * *$ & 0,3015141 & 0,736 & 0,3626194 & $0,013 * *$ \\
\hline \multicolumn{7}{|c|}{ Place of Residence (2) } \\
\hline Urban & 0,3257122 & $0,000 * * *$ & 0,6723684 & 0,105 & 0,3059683 & $0,000 * * *$ \\
\hline \multicolumn{7}{|c|}{ Professional Experience } \\
\hline Age & 0,0833426 & $0,000 * * *$ & 0,1094901 & $0,016 * *$ & 0,0940604 & $0,000 * * *$ \\
\hline $\mathrm{Age}^{2}$ & $-0,0008258$ & $0,002 * * *$ & $-0,001169$ & $0,048 * *$ & $-0,0009329$ & $0,000 * * *$ \\
\hline Years of experience & 0,0088576 & $0,065^{*}$ & $-0,0105364$ & 0,336 & 0,0109981 & $0,004 * * *$ \\
\hline Vocational training & 0,1195646 & $0,037 * *$ & 0,1156438 & 0,266 & 0,118603 & $0,015 * *$ \\
\hline \multicolumn{7}{|c|}{ Socio-professional Cat.(3) } \\
\hline Staff & 0,7837137 & $0,000 * * *$ & 0,7692045 & $0,000 * * *$ & 0,7874493 & $0,000 * * *$ \\
\hline Employee & 0,0135557 & 0,835 & 0,0414399 & 0,794 & 0,0061343 & 0,908 \\
\hline
\end{tabular}




\begin{tabular}{|c|c|c|c|c|c|c|}
\hline \multirow{2}{*}{ Variable } & \multicolumn{2}{|l|}{ Set } & \multicolumn{2}{|l|}{ Male } & \multicolumn{2}{|l|}{ Female } \\
\hline & Coef & P. value & Coef & P. value & Coef & P. value \\
\hline Own account & 0,594735 & $0,033 * *$ & 0,2910613 & 0,474 & 0,6422325 & $0,015^{* *}$ \\
\hline \multicolumn{7}{|l|}{ Size of the Company (4) } \\
\hline Between 3 and 5 workers & 0,5181507 & $0,033 * *$ & 0,7117289 & $0,089 *$ & 0,4690239 & $0,034 * *$ \\
\hline More than 5 workers & 0,3632909 & 0,113 & 0,1914426 & 0,612 & 0,4108058 & $0,050^{*}$ \\
\hline \multicolumn{7}{|l|}{$\operatorname{Sex}(5)$} \\
\hline Male & $-0,1264811$ & $0,046^{* *}$ & ----- & ---- & ----- & ---- \\
\hline Constancy of regression & 1,309276 & $0,016 * *$ & 1,028757 & 0,564 & 0,7173941 & $0,019 * *$ \\
\hline Lambda & $-0,943482$ & 0,384 & $-0,3516202$ & $0,093^{*}$ & -0.2739962 & 0,754 \\
\hline Wald chi2 & 443,87 & & 739,80 & & 108,94 & \\
\hline P. value & 0,000 & & 0,000 & & 0,000 & \\
\hline
\end{tabular}

$* * *, * *$, and $*$ means significant $1 \%, 5 \%$, and $10 \%$, respectively. $(1)$ is not in the reference threshold, (2) the reference is "rural setting", $(3)$ the reference "caregivers, laborer, apprentice", (4) the reference is "less than 3 workers", and (5) the reference is "female".

Source: Authors' estimates, from SEIS1 with Stata 12

When one considers the non-agricultural informal sector, it is arguable that women would gain much by going through higher levels of education. As a matter of fact, the high coefficient of the variable "secondary or higher education"; as compared to the variable "primary education", shows that women's income improves with the level of education (Table 9). In addition, the increase of human capital for women could help increase their integration into larger companies. Table 9 shows that the size of the company is an important determinant of income for women in the non-agricultural informal sector. As to the formal sector, vocational training is a basic variable in reducing gender discrimination in the non-agricultural informal sector.

Table 9. Estimates of the Wage Equation in the Non-Agricultural Sector

\begin{tabular}{|c|c|c|c|c|c|c|}
\hline \multirow{2}{*}{ Variable } & \multicolumn{2}{|c|}{ Set } & \multicolumn{2}{|c|}{ Male } & \multicolumn{2}{|c|}{ Female } \\
\hline & Coef & P. value & Coef & P. value & Coef & P. value \\
\hline \multicolumn{7}{|l|}{ Level of Education (1) } \\
\hline Primary & 0,3930256 & $0,000 * * *$ & 0,5298537 & $0,000 * * *$ & 0,216059 & $0.005 * * *$ \\
\hline Secondary-higher & 0,6329177 & $0,000 * * *$ & 0,7794485 & $0,000 * * *$ & 0,4041826 & $0,000 * * *$ \\
\hline \multicolumn{7}{|l|}{ Place of Residence (2) } \\
\hline Urban & 0,1895458 & $0,000 * * *$ & 0,1749226 & $0,000 * * *$ & 0,1837438 & $0,000 * * *$ \\
\hline \multicolumn{7}{|l|}{ Professional Experience } \\
\hline Age & 0,0396067 & $0,000 * * *$ & 0,0677713 & $0,000 * * *$ & 0,0371269 & $0,016^{* *}$ \\
\hline $\mathrm{Age}^{2}$ & $-0,0004736$ & $0,000 * * *$ & $-0,0006946$ & $0,000 * * *$ & $-0,0004844$ & $0,004 * * *$ \\
\hline Years of experience & 0,012403 & $0,000 * * *$ & 0,0136445 & $0,000 * * *$ & 0,0103116 & $0,006^{* * *}$ \\
\hline Vocational training & 0,029975 & 0,491 & $-0,0054704$ & 0,945 & 0,0426842 & 0,575 \\
\hline \multicolumn{7}{|l|}{ Socio-professional Cat.(3) } \\
\hline Staff & 0,5178014 & $0,000 * * *$ & 0,6331864 & $0,000 * * *$ & 0,4400616 & $0,010 * *$ \\
\hline Employee & 0,0391139 & 0,279 & 0,0740691 & 0,372 & 0,019841 & 0,737 \\
\hline Own account & $-0,1025269$ & $0,002 * * *$ & $-0,2593604$ & $0,000 * * *$ & $-0,0214345$ & 0,706 \\
\hline \multicolumn{7}{|l|}{ Size of the Company (4) } \\
\hline Between 3 and 5 workers & 0,1175646 & $0,000 * * *$ & 0,1125305 & $0,024 * *$ & 0,1239956 & $0,030 * *$ \\
\hline More than 5 workers & 0,2121341 & $0,000 * * *$ & 0,3760687 & $0,000 * * *$ & 0,1994564 & $0,003 * * *$ \\
\hline \multicolumn{7}{|l|}{$\operatorname{Sex}(5)$} \\
\hline Male & $-0,5212722$ & $0,000 * * *$ & ---- & ----- & ---- & ----- \\
\hline Constancy of regression & 2,221447 & $0,000 * * *$ & 2,504452 & $0,001 * * *$ & 0,9052947 & $0,000 * * *$ \\
\hline Lambda & $-0,9270501$ & $0,000 * * *$ & $-0,1782702$ & $0,000 * * *$ & $-1,34387$ & $0,000 * * *$ \\
\hline Wald chi2 & \multicolumn{2}{|c|}{1830,42} & \multicolumn{2}{|c|}{134,19} & \multicolumn{2}{|c|}{801,84} \\
\hline P. value & \multicolumn{2}{|c|}{0,000} & \multicolumn{2}{|c|}{0,000} & \multicolumn{2}{|c|}{0,000} \\
\hline
\end{tabular}

*** and ** means significant $1 \%$ and $5 \%$, respectively. (1) is not in the reference threshold, (2) the reference is "rural setting", (3) the reference "caregivers, laborer, apprentice", (4) the reference is "less than 3 workers", and (5) the reference is "female".

Source: Authors' estimates, from SEIS1 with Stata 12

In Table 10, the non-significance of the coefficient at the primary level shows that the informal agricultural sector requires a high school education or even higher education for women. As for the other two sectors, vocational training appears as a basic variable for reducing gender discrimination in the informal agricultural sector. But seniority appears as a criterion of discrimination. This can be explained by the fact that women stop their productive activity early (at an earlier age than men), to carry out household activities. 
Table 10. Estimates of the Wage Equation in the Non-Agricultural Sector.

\begin{tabular}{|c|c|c|c|c|c|c|}
\hline \multirow{2}{*}{ Variable } & \multicolumn{2}{|l|}{ Set } & \multicolumn{2}{|l|}{ Male } & \multicolumn{2}{|l|}{ Female } \\
\hline & Coef & P. value & Coef & P. value & Coef & P. value \\
\hline \multicolumn{7}{|l|}{ Level of Education (1) } \\
\hline Primary & 0,2082387 & $0,000 * * *$ & 0,3767739 & $0,000 * * *$ & 0,0518238 & 0,389 \\
\hline Secondary-higher & 0,4292601 & $0,000 * * *$ & 0,6127806 & $0,000 * * *$ & 0,2608253 & $0,000 * * *$ \\
\hline \multicolumn{7}{|l|}{ Place of Residence (2) } \\
\hline Urban & 0,2276439 & $0,000 * * *$ & 0,1560447 & $0,005 * * *$ & 0,3434391 & $0,000 * * *$ \\
\hline \multicolumn{7}{|l|}{ Professional Experience } \\
\hline Age & 0,0655034 & $0,000 * * *$ & 0,0886338 & $0,000 * * *$ & 0,0474894 & $0,000 * * *$ \\
\hline $\mathrm{Age}^{2}$ & $-0,0006922$ & $0,000 * * *$ & $-0,0009004$ & $0,000 * * *$ & $-0,0005183$ & $0,000 * * *$ \\
\hline Years of experience & 0,0049396 & $0,002 * * *$ & 0,0081088 & $0,000 * * *$ & 0,0022731 & 0,328 \\
\hline Vocational training & 0,684498 & $0,045^{* *}$ & 0,0330241 & 0,973 & 0,7861153 & $0,036^{* *}$ \\
\hline \multicolumn{7}{|l|}{ Socio-professional Cat.(3) } \\
\hline Staff & $-2,292841$ & $0,018^{* *}$ & 0 & ---- & $-2,629252$ & $0,008 * * *$ \\
\hline Employee & 0,3656234 & $0,090 *$ & $-0,6846099$ & 0,472 & 0,2328729 & 0,305 \\
\hline Own account & $-0,199626$ & $0,000 * * *$ & 0,0075471 & 0,922 & $-0,40979$ & $0,000 * * *$ \\
\hline \multicolumn{7}{|l|}{ Size of the Company (4) } \\
\hline Between 3 and 5 workers & 0,0189771 & 0,607 & 0,0628171 & 0,211 & $-0,0376022$ & 0,488 \\
\hline More than 5 workers & 0,123253 & $0,077 *$ & 0,0601831 & 0,592 & 0,1260078 & 0,156 \\
\hline \multicolumn{7}{|l|}{$\operatorname{Sex}(5)$} \\
\hline Male & $-0,443217$ & $0,000 * * *$ & ----- & ----- & ----- & ----- \\
\hline Constancy of regression & 1,12712 & $0,000 * * *$ & 1,942074 & 0,457 & $-0,3988103$ & $0,000 * * *$ \\
\hline Lambda & 0,0332176 & 0,809 & 0,5079004 & $0,027 * *$ & $-0,3479306$ & $0,007 * * *$ \\
\hline Wald chi2 & 479,24 & & 160,07 & & 143,67 & \\
\hline P. value & 0,000 & & 0,000 & & 0,000 & \\
\hline
\end{tabular}

$* * *, * *$, and * means significant $1 \%, 5 \%$, and $10 \%$, respectively. (1) is not in the reference threshold, (2) the reference is "rural setting", (3) the reference "caregivers, laborer, apprentice", (4) the reference is "less than 3 workers", and (5) the reference is "female".

Source: Authors' estimates, from SEIS1 with Stata 12

From the Lambda variable coefficients which are not significant in some segments, we can conclude that the wages are not significantly influenced by the non-random allocation of individuals in these segments. This is the case for example of women in the formal sector.

\subsubsection{Employee Discrimination by Gender in Different Segments}

Table 11 shows that in terms of income (salary), men have more advantage in the informal sector than women. In fact, the income gap due to gender discrimination (unexplained gap) tends to disappear in the formal sector (men earn on average $12 \%$ more than women). Conversely, the income gap due to the simple fact of being male or female is higher in the informal agricultural sector (1.36); followed by the non-agricultural informal sector $(87.7 \%)$, and is only advantageous for men.
These large differences are due to the fact that in the informal sector, wages are directly linked to the performance of the workforce. Unfortunately, the female labor force is generally less than that of men. One cause of this is related to the fact that women spend about one-third of their time doing house works and monitoring their reproduction cycle (medical visits and maternity leave). In addition, women face enormous difficulties in getting loans from banks (in business, bank loans are a pillar of productivity). This difficulty is partly due to the fact that less than $15 \%$ of the female population is landowner [28]. The latter (landowning) is the main guarantee required by financial institutions in Cameroon. The fact that the formal sector is characterized by a regulated system, limits non-compensating wage disparities and discriminatory practices.

Table 11. Income Gap between Men and Women within the Segments.

\begin{tabular}{llccc}
\hline \multicolumn{1}{c}{ Gap } & \multicolumn{1}{c}{ Formula } & Formal & Non-agricultural informal sector & $\begin{array}{c}\text { Values within Sectors } \\
\text { Agricultural informal sector }\end{array}$ \\
\hline Male advantage (1) & $\bar{X}_{m}\left(\beta_{m}-\beta_{n}\right)$ & 0,37206429 & 0,631075968 & 0,633289905 \\
Female disadvantage $(2)$ & $\bar{X}_{f}\left(\beta_{n}-\beta_{f}\right)$ & $-0,251008707$ & 0,246155239 & 0,731111414 \\
Unexplained gap(3) & $(1)+(2)$ & 0,121055583 & 0,877231207 & 1,364401318 \\
Explained gap (4) & $\hat{\beta}_{n}\left(\bar{X}_{m}-\bar{X}_{f}\right)$ & 0,135202336 & $-0,154300416$ & 0,010234586 \\
Total gap & $(3)+(4)$ & 0,256257919 & 0,722930791 & 1,374635904 \\
\hline
\end{tabular}

Source: Authors' estimates, from SEIS1 
As concerns wage gap associated with differences in characteristics between men and women, they are higher in the formal and informal sectors. It should be noted that these wage gaps are explained by the average skills of men and women; such as the level of education which gives the possibility to occupy certain socio-professional categories. In fact, men are more likely to enter higher education and occupy positions of manager and executive. However, women tend to be concentrated in positions of subordination (secretary, treasurer, etc.), characterized by precarious wages. The negative sign on the explained gap in the non-agricultural informal sector permits to stick on the characteristics of this sector. Indeed, the majority of women work on their own account and for the rest, they usually work in small size companies (usually less than 5 people): which limits discrimination. As to the agricultural informal sector, there is no explained wage gap: which shows that the only criterion of discrimination in this area is linked to the performance of the workforce.

In sum, the informal agricultural sector is the most discriminating against women (1.37), followed by the non-agricultural informal sector $(72.3 \%)$. These results suggest that women may be victims of discrimination when market mechanisms without proper regulations exist: which is the case in the informal sector.

\section{Conclusions and Recommendations}

The main objective of this research was to propose ways and means of reducing gender inequality in the labor market in Cameroon. It used the classification by dynamic cloud to identify the different segments of the labor market and the decomposition method of Oaxaca and Blinder to quantify the gender discrimination; so as to highlight the factors that provoke discrimination. The results show that the labor market has three segments. The segment with the highest gender inequality; based on the participation of men and women, is the formal sector. Women are more represented in segments compatible with chores. These segments are characterized by job instability and low income (non-agricultural informal sector and agricultural informal sector). The segment with the largest gender inequality in terms of remuneration is the informal agricultural sector, followed by the non-agricultural informal sector, and finally the formal sector.

Based on these findings, observations can be geared towards three aspects. First, the level of education is low among women. In addition to the low level of education, women stop studies early. The NIS [28] showed that the high school completion rate is higher among male students than among females. Second, the precarious sector (agricultural-informal) consists mostly of women. Third, women are victims of wage inequality in all segments of the labor market. From the preceding observations on the Cameroonian, and in reference to Gneezy, List and Price [36] who propound that one of the main causes of gender discrimination is the low level of women's instruction, we recommend that the government develop policies that favor female education and vocational training for girls. These policies include reducing tuition fees, and granting incentives to schooled girls. These measures aim not only at reducing differences between men and women at the educational level, but they also seek to increase opportunities for women; especially as concerns high positions in public and private companies. More so, the government should elaborate strategies favoring women on the labor market as a whole, notably by developing sanction measures against companies or employers who offer different salaries to men and women for the same work.

\section{References}

[1] Institut National de la Statistique (2001), Pauvreté et Education au Cameroun en 2001, INS, Yaoundé.

[2] Institut National de la Statistique (2007), Enquête Camerounaise Auprès des Ménages (ECAM).

[3] Programme des Nations Unies pour le Développement (2009), Indice Sexospécifique de Développement Humain, Rapport sur le développement humain.

[4] Knowles, S., Lorgelly, P. and Owen, D., (2002), Are Educational Gender Gaps a Break on Economic Development?, Oxford Economic Papers vol. 54, PP. 118-149

[5] Ellis, A., Manuel, C. and Blackden, M. (2006), Gender and Economic Growth in Uganda: Unleashing the power of women, IBRD-World Bank.

[6] Klasen, S. (2008), Gender Inequality, Growth and Poverty Reduction in Cameroon: Evidence and policy issus, University of Göttingen, Germany.

[7] Costa J. and Silva E., (2008), The Burden of Inequality for Society. Dans: Poverty in Focus, Gender Equality. $\mathrm{N}^{\circ} 13$.

[8] Klasen, S. (1999), Does Gender Inequality Reduce Growth and Development? Evidence from Cross-Country Regressions, Policy Research Report, Engendering Development, Working Paper No. 7. World Bank, Washington, D.C.

[9] Golla, A, Malhotra A., Nanda P. and Mehra R. (2011), Understanding and Measuring Women's economic empowerment. Definition, framework, indicators, Washington DC: International Centre for Research on Women.

[10] Oaxaca R. L. (1973), Male-Female Wage Differentials in Urban Labor Markets, International Economic Review, vol. 14, PP. 693-709.

[11] Blinder A.S. (1973), Wage Discrimination: Reduced Form and Structural Estimates, The Journal of Human Resources, vol. 8, PP. 436-455.

[12] Njikam G. B., Tchoffo, R. M. and Mwaffo, V. F., (2005), Caractéristiques et Déterminants de l'Emploi Jeune au Cameroun, Cahiers de la Stratégie de l'Emploi, ILO 2005/05 
[13] Pignatti, N. (2010), Labor Market Segmentation and Gender Wage Gap in Ukraine, ESCIRRU Working Paper N 17.

[14] Leduc, K. and Genevois A-S. (2012), Segmentation du Marché du Travail - Le cas Luxembourgois, CEPS, Working paper.

[15] Mincer, J., and Polachek, S., (1974), Family Investments in Human Capital: Earning of Women, dans Economics of the Family sous la direction de Théodore W. Schultz Chicago, the University of Chicago Press.

[16] Polacheck S. W. (1981), Occupational Self Selection: A Human Capital Approach to Sex Differences in Occupational Structure, Review of Economics and Statistics Vol. 63, N. 1, PP. 60-69.

[17] Organisation Internationale du Travail (2009), Tendances Mondiales de 1Emploi des Femmes.

[18] Hicks, H., R. (1936), The Theory of Wages, Macmillian, New York.

[19] Becker, G. (1971), The Economics of Discrimination, Chicago: University of Chicago Press.

[20] Arrow, K. (1973), The Theory of Discrimination, in O. Ashenfelter and A. Rees (eds) Discrimination in Labor Markets Princeton NJ: Princeton University Press.

[21] Edgeworth, F., Y. (1922), Equal Pay to Men and Women for Equal Work, Economic Journal, Vol. 22.

[22] Folbre, N. (1994), Who Takes Care of the Kids? Gender and the structures of constraint, Routledge: London and New York.

[23] Figart, D. (2005), Gender as more than a Dummy Variable: Feminist Approaches to Discrimination, Review of Social Economy Vol. 63, N 3, PP. 509-536

[24] Bergmann, B. (1974), Occupational Segregation. Wages and Profits when Employers Discriminate by Race or Sex, Eastern Economic Journal Vol. 1, N², PP. 103-110.
[25] Phillips, A. and B. Taylor (1980), Sex and Skills: Notes Towards a Feminist Economics, Feminist Review Vol. 6, PP. 79-88.

[26] Arneson R. (1989), Equality of Welfare, Philos stud, $\mathrm{N}^{\circ} 56$, PP. 77-93.

[27] Roemer, J. E. (1998), Equality of Opportunity, Cambridge, MA: Havard University Press.

[28] Institut National de la Statistique (2011), Deuxième Enquête sur L'emploi et le Secteur Informel au Cameroun, Rapport principal, phase1.

[29] Organisation Internationale du Travail (2013), « Rapport mondial sur les salaires 2012/2013: salaires et croissance équitable », Genève.

[30] Brilleau A., Coulibaly S., Gubert F., Koriko O., Kuepie M. and Ouedraogo E. (2005), Le secteur informel: Performances, Insertion, Perspectives, Enquête 1-2-3, phase 2, Statéco n 99.

[31] Mincer J. (1974), Schooling, Experience and Earnings, NBER, Columbia University Press, New York.

[32] Oaxaca, R. L. and Ransom M. R. (1994), On Discrimination and the Decomposition of Wage Differentials, Journal of Econometrics, Vol. 61, N 1, PP. 5-21.

[33] Heckman J. J. (1979), Sample Selection Bias as Specification Error, Econometrica, Vol.47, N1, PP.153-161.

[34] Winship, C. (1992), Models for Sample Selection Bias', Annual Reviews, vol. 18, PP. 325-350.

[35] Thomas M. and Vallée (1996), Labor Market Segmentation in Cameroonian Manufacturing, the Journal of Development Studies, Vol.32, N6, PP. 876-898.

[36] Gneezy, U., List, J., and Price, M. K. (2012), Toward an Understanding of Why People Discriminate: Evidence from a Series of Natural Field Experiments, NBER Working Paper 17855. 